\title{
Correction to: Effect of Copper Loading in Copper-Alumina Aerogels on Three-Way Catalytic Performance
}

\author{
Ann M. Anderson ${ }^{1}$ (D) $\cdot$ Bradford A. Bruno ${ }^{1} \cdot$ Frank Dilone $^{1} \cdot$ Matthew T. LaRosa $^{1} \cdot$ Thomas F. Andre $^{2}$. \\ Chris Avanessian ${ }^{2} \cdot$ Mary K. Carroll $^{2}$
}

Published online: 19 October 2020

(C) Springer Nature Switzerland AG 2020

Correction to: Emission Control Science and Technology (2020) 6:324-335. https://doi.org/10.1007/s40825-020-00165-z

The original version of this article contained 2 errors.

Error 1: In the methods and materials section, the paragraph entitled "Aerogel Synthesis" the units for the force value are incorrect. It is listed in N. It should be $\mathrm{kN}$. The correct sentence is:

The mold was then sealed using a 200-kN load and heated to a supercritical state of $249^{\circ} \mathrm{C}$ at a rate of $3.8^{\circ} \mathrm{C} / \mathrm{min}$ with a constant load of $200 \mathrm{kN}$. Upon reaching $249^{\circ} \mathrm{C}$, the system dwelled for $30 \mathrm{~min}$ to allow the system to equilibrate. The press force was then decreased to $4.4 \mathbf{k N}$ at a rate of 4.4 $\boldsymbol{k N} /$ min which allowed supercritical fluid to escape from the mold. After a 15-min dwell, the mold was then cooled to $32^{\circ} \mathrm{C}$ at a rate of $3.8^{\circ} \mathrm{C} / \mathrm{min}$. The entire RSCE process took approximately $4 \mathrm{~h}$.

Error 2: The name of the second author is Bradford A. Bruno, not Braford A. Bruno.

Publisher's Note Springer Nature remains neutral with regard to jurisdictional claims in published maps and institutional affiliations.
The online version of the original article can be found at https://doi.org/ $10.1007 / \mathrm{s} 40825-020-00165-\mathrm{Z}$

Ann M. Anderson

andersoa@union.edu

1 Department of Mechanical Engineering, Union College, Schenectady, NY 12308, USA

2 Department of Chemistry, Union College, Schenectady, NY 12308, USA 